\title{
Pemanfaatan media wordwall dalam peningkatan perbendaharaan kosakata (vocabulary) pada pembelajaran bahasa Inggris
}

\author{
Nila Wati Idrus 1, Dwi Yulianti 2, Ujang Suparman 3, Zainal Abidin \\ Arief 4 \\ 1,2,3 University of Lampung, 4 Universitas Ibn Khaldun \\ Correspondence : nilawati.idrus@gmail.com
}

\begin{abstract}
Penelitian ini bertujuan untuk: (1) mengembangkan media wordwall yang layak dalam peningkatan siswa dalam pembelajaran Bahasa Inggris (2) mengetahui keberhasilan penggunaan media belajar pada mata pelajaran bahasa Inggris, khususnya dalam upaya guru meningkatkan perbendaharaan kosakata siswa. Subjek Penelitian ini adalah siswa SMP Negeri 34 Bandar Lampung. Peserta didik dapat dikatakan mampu dalam pembelajaran Bahasa Inggris apabila mempunyai kemampuan lebih yang dimilik yakni kosakata. Menggunakan media yang mendukung dalam pembelajaran kosakata membuat peserta didik lebih memahaminya dibandingkan menggunakan pembelajaran tanpa menggunakan media. Tidak hanya peserta didik membutuhkan pemahaman kosakata yang banyak, seorang pendidik juga harus mempunyai perbendaharaan kosakata yang lebih banyak. Disesuaikan dengan materi yang diajarkan apabila pendidik mengajar tentang menulis paragraf sederhana, pendidik mampu memberikan aspek-aspek penilaian dalam menulis. Selanjutnya pemberian pembelajaran kosakata, pendidik mampu menjelaskan makna kosakata yang ada sehingga sebuah makna kosakata yang mempunyai arti secara berhubungan dapat menjadi bahasa yang mempunyai makna. Wordwall adalah sebuah aplikasi yang menarik pada browser. Aplikasi khusus yang bertujuan sebagai sumber belajar, media, dan alat penilaian yang menyenangkan bagi murid. Selain itu juga gratis penggunaannya dapat dishare lansung melalui facebook, goggle classroom, twitter, atau melalui link ke grup WA. Media wordwall diharapkan membantu siswa dalam pemahaman kosakata siswa tanpa harus selalu tergantung pada penggunaan kamus. Di dalam melakukan penelitian menggunakan R \& D atau yang lebih dikenal dengan Research atau Development yang mengutip versil Borg dan Gall. Kajian deskriptif analisis mengarah pada petunjuk pembelajaran Dick and Carey yang mempunyai tahapan terdiri penyelidikan kebutuhan, rancangan pembelajaran, penerapan pengembangan produk, verifikasi dan perbaikan produk. Pengamatan, penyebaran angket, dan evaluasi sebagai langkah untuk mendapatkan data. Statistik penyebaran diperlukan sebagai evaluasi deskriptif kuantitatif. Perolehan hasil belajar menggunakan normalisasi atau lebih
\end{abstract}


dikenal N-gain mempunyai fungsi melihat sejauh mana efisiensi pemanfaatan gawai wordwall tersebut. Hasil penilaian dari ahli materi 4.34 Kategori sangat baik. Hasil validasi media 3.70. Dengan kategori baik. Riset membuktikan: (1) pemanfaatan dalam pembuatan media wordwall salah satu pembelajaran meliputi, keahlian, bahan ajar, glossary, evaluasi serta berbagai jenis permainan dalam gawai tersebut, (2) pemanfaatan media wordwall dapat di implementasikan untuk sumber belajar khususnya pembelajaran perbendaharaan kosakata.

Kata kunci: media interaktif, Wordwall, perbendaharaan kata

\section{Pendahuluan}

Pandemi saat ini terjadi di penjuru dunia. Termasuk di negara Indonesia terjadi bulan Februari 2020. Dampak dari Covid-19 di dunia pendidikan mengalami perubahan yang awalnya pembelajaran dilakukan tatap muka. Tetapi untuk menghindari penularan Covid-19 pendidik memberikan materi melalui virtual atau menggunakan platform yang sudah banyak disediakan. Pendidik diharapkan terus melaksanakan pembelajaran kepada peserta didik. Pendidik sebagai sebagai fasilitator didalam pembelajaran, mampu memberikan media pembelajaran kepada peserta didik untuk menghindari peserta didik dari kejenuhan selama pembelajaran secara online. Salah satunya dalam pembelajaran Bahasa Inggris dibutuhkan media untuk membantu dalam pembelajaran. Untuk memudahkan percakapan terjalin dua arah dibutuhkan komunikasi yang baik mempunyai peranan penting untuk mewujudkan informasi tersebut dapat tersampaikan. Melalui Bahasa serangkaian kosakata dijadikan satu kesatuan menjadi sebuah kalimat yang mempunyai makna. Penguasaan kosakata dalam pembelajaran Bahasa merupakan hal penting terutama pada pembelajaran Bahasa Inggris. Dalam belajar Bahasa Inggris seseorang akan mampu memahami Bahasa dengan baik dan lancar, apabila seseorang menguasai banyak kosakata dalam Bahasa Inggris sudah jelas mengetahui arti dan makna kata. Proses kegiatan pembelajaran pada peserta didik dikatakan mampu memahami pembelajaran Bahasa Inggris, menguasai keterampilan receiptive (mendengarkan dan membaca) dan keterampilan productive (berbicara dan menulis). Dalam menguasai keterampilan utama pembelajaran Bahasa inggris yakni keterampilan receiptive dan productive sangat diperlukan perbendaharaan kosakata yang kaya untuk memudahkan peserta didik memahami kegiatan proses pembelajaran Bahasa Inggris.

Menurut Felder \& Prince, 2000; mukoroli, 2011; Schmit \& Schmit, 2014, kegiatan pembelajaran peserta didik indikator keberhasilan dilihat dari pemahaman kosakata peserta didik. Komunikasi dapat berjalan dengan baik, diperlukan lawan bicara yang mampu memahami kosakata yang disampaikan. Ini dapat dipahami bahwa dalam kegiatan sehari-hari diperlukan kosakata untuk menyampaikan sebuah pesan yang ingin disampaikan. Oleh karena itu, seorang siswa yang belajar bahasa asing diharapkan dapat mengerti dan memahami sistem perbendaharaan kata. Seorang guru, dalam hal ini sebagai fasilitator dan memberi motivasi siswa, serta membantu mereka dalam upaya memperkaya dan meningkatkan perbendaharaan kosakata. Penggunaan alat bantu/media dalam upaya meningkatkan kosakata siswa sangat dianjurkan. Menurut, Walter Dick 
dan Lou Carey (2005,p.205) mendefinisikan pembelajaran sebagai rangkaian peristiwa atau kegiatan yang didampaikan secara terstruktur dan terencana dengan menggunakan sebuah atau beberapa jenis media. Proses pembelajaran mempunyai tujuan agar siswa dapat mencapai kompetensi seperti yang diharapkan. Gagne (1985) mengemukakan konsep events of instruction yang terkait dengan pemrosesan informasi yang dapat mengarahkan kepada terjadinya proses belajar yang efektif dan efisien. Menurut teori belajar yang dikemukakan oleh Gagne, teori ini merupakan bentuk rangkaian didalam langkah belajar dengan mengkondisikan situasi belajar berdasarkan saat peristiwa belajar, diproses melalui kemampuan belajar peserta didik. Dengan demikian di dalam proses pembelajaran terdapat kegiatan yang kompleks. Sehingga pendidik diperlukan menyiapkan media yang interaktif. Dengan demiikian, masalah utama yang ingin diungkapkan adalah kurangnya perbendaharaan kosakata peserta didik pada kelas VII di UPT SMPN 34 Bandar Lampung. Pembelajaran yang diberikan masih konvensional. Pendidik mengajar kosakata melalui hafalan (memorizing), menimbulkan kejenuhan bagi peserta didik. Dari pemaparan tersebut dapat disimpulkan bahwa pembelajaran tersebut membuat peserta didik merasa bosan sehingga perlu diciptakan proses pembelajaran dan media yang menyenangkan.

Media secara umum merupakansuatu perantara dalam pembelajaran. Sedangkan menurut Kamus besar Bahasa Indonesia (KBBI), interaktif adalah sifat saling melakukan aksi, antarhubungan, saling aktif. Berdasarkan pernyataan di atas, pembelajaran yang interaktif merupakan suatu perantara yang digunakan dalam proses pembelajaran dimana pengirim dan penerima pesan saling melakukan interaksi satu sama lain. Hal ini diperkuat oleh Arrosyida (2015: 3) yang menyatakan bahwa media pembelajaran interaktif adalah sesuatu yang menyangkut software dan hardware yang dapat digunakan sebagai perantara untuk menyampaikan isi materi ajar dan sumber belajar ke pembelajar dengan metode pembelajaran yang dapat memberikan respon baik terhadap pengguna.

Dapat disimpulkan untuk mendapatkan media pembelajaran dapat berupa alat, lingkungan ataupun kegiatan yang digunakan untuk menyampaikan pesan, stimulus dan memotivasi siswa sehingga tercapainya tujuan pembelajaran secara efektif dan efisien serta tepat guna. Dapat disimpulkan bahwa media merupakan alat yang digunakan untuk menyampaikan informasi yang sulit untuk ditemui secara langsung, sehingga menjadi perantara penyampai sebuah informasi.

Penelitian ini dilaksanakan untuk mengetahui sejauh mana pembelajaran Bahasa Inggris dapat menggunakan media Wordwall sehingga dapat mengembangkan perbendaharaan kosakata (Vocabulary) peserta didik di masa pademi dibandingkan dengan menggunakan media bacaan/teks biasa. Manfaat dari penelitian ini dapat memberi atmosfer dalam mengembangkan perbendaharaan kosakata siswa melalui media Wordwall.

Media wordwall diharapkan membantu peserta didik dalam pemahaman kosakata peserta didik tanpa harus bergantung pada penggunaan kamus atau juga arti kata yang diberikan oleh guru (Wagstaf,1999). Juga mengungkapkan bahwa wordwall salah satu cara agar peserta didik melakukan praktek dan tidak hanya membaca buku rujukan dari seorang guru. 
Penggunaan media Wordwall untuk membantu tujuan pembelajaran. Pembelajaran bisa lebih menarik. Media dapat digunakan sebagai penarik perhatian dan membuat tetap konsentrasi dan peserta didik memperhatikan degan baik. Dan menjadi susasana kelas lebih menyenangkan.

\section{Metode Penelitian}

Langkah-langkah dalam penelitian disini menggunakan R \& D atau Research and Development, fokus penelitian ini diarahkan pada mengembangkan media pembelajaran. Wordwall adalah salah satu gawai yang ada, bertujuan untuk menunjang alat bantu untuk mengatasi pembelajaran Bahasa inggris dimasa pandemi. Didalam mengajarkan perbendaharaan kosakata. Penelitian dilakukan disekolah UPT SMPN 34 Banda Lampung kelas VII. Jumlah keseluruhan responden sebanyak 31 siswa.

Kerangka fikir dalam prosedur pengembangan produk media pembelajaran Wordwall menggunakan model Borg \& Gall, Dick \& Carey. Prosedur yang digunakan meliputi analisis kebutuhan, pengembangan desain pembelajaran pengembangan produk validasi dan revisi terhadap konten pembelajaran Wordwall.

Terdapat 6 peserta didik untuk dilakukan uji beta, 2 peserta didik untuk menggantikan level atas, 2 peserta didik menggantikan untuk level sedang kemudian 2 peserta didik menggantikan level bawah, untuk mendapatkan hasil ketentuan tingkatan tersebut perlu diterapkan oleh peneliti dengan melakukan pengamatan saat proses pembelajaran didalam kelas dan di ikuti akhir hasil pembelajaran pada semester yang telah dilalui sebelumnya. Pelaksasanaan evaluasi diberikan kepada 31 peserta didik pada kelas VII. Berikut langkahlangkah prosedur yang digunakan dalam penelitian pengembangan; (1) perencanaan terdiri dari: mendefinisikan bidang atau ruang lingkup, dengan cara mengidentifikasi karakteristik peserta didik untuk mengetahui pemahaman peserta didik, membuat arsip perencanaan, menentukan dan mengumpulkan data-data yang mendukung pada saat penelitian, untuk kemudian melakukan brainstorming; (2) Perancangan terdiri dari: melakukan tahap analisis konsep dan cakupan materi, kemudian langkah selanjutnya membuat flowchart, mengembangkan pembuatan layout, mencari sumber-sumber yang berkaitan dengan konten, menentukan software yang tepat untuk digunakan; (3) Tahap pengembangan terdiri dari: membuat web melalui domain dan hosting, mengembangkan pada materi wacana, beberapa komponen disatukan untuk menjadi satuan yang utuh (konten audio, video dan teks), menyediakan bahan ajar yang dapat mendukung, sehingga pemanfaatan Wordwall siap diaplikasikan saat uji alfa.

Dalam menguji data untuk menunjang keperluan penelitian dan pengembangan menggunakan jenis penelitian kualitatif dan kuantitatif. Pengambilan prasurvey diperoleh melalui langkah wawancara kemudian analisis kebutuhan diproses untuk data kualitatif pada tahap uji coba awal. Tim verikasi ahli media dan materi mempunyai peranan yang berbeda-beda. Seperti untuk pengolahan data kuantitatif dan analisa deskriptif diperlukan kerjasamanya dari para verifikasi ahli dan materi kemudian hasil data-data tersebut dianalisis dengan 
menggunakan skala 5. Hasil pretest dan posttest diperoleh melalui data kuantitatif

Hasil perolehan tersebut digunakan sebagai acuan sejauh mana skala 5 dapat membantu keberhasilan pemanfaatan gawai wordwall dalam hal ini membantu peserta didik untuk menambah perbendaharaan kosakata. Untuk memodifikasi aktifitas proses pembelajaran Bahasa Inggris kepada peserta didik. Data-data tersebut diperlukan sebagai bahan acuan dalam memperbaiki penggunaan bahan ajar Wordwall yang dikembangkan.

Wawancara, angket, dan tes hasil belajar adalah instrumen yang digunakan dalam penelitian pemanfaatan wordwall. Tahap awal dalam wawancara melakukan presurvey, bertujuan untuk melakukan sejauh mana analisis kebutuhan pemanfaatan wordwall pada peserta didik. Kemudian, dilakukan penyebaran angket sebagai penilaian oleh verifikasi ahli media materi dan mengetahui sejauh mana respon dari koresponden. Pretest dan posttest bermanfaat sebagai tes hasil belajar. Validator instrumen berfungsi sebagai memvalidasi seluruh instrument yang digunakan. Sedangkan untuk mendapatkan evalauasi proses belajar diperlukan verifikasi oleh pakar bahan ajar.

Evaluasi kualitatif pada penelitian ini terdapat dari beberapa pakar media dan pakar bahan ajar memberikan perbaikan pada penelitian, yang bertujuan mendapatkan hasil pemanfaatan wordwall untuk dikembangkan. Untuk pengolahan evaluasi kualitatif yang terdiri dari rasio likert yang di transfigurasi sangat baik, baik, cukup, kurang baik dan tidak baik perolehan ini didapat berdasarkan informasi yang diberikan oleh pakar instrumen, pakar bahan ajar dan pelajar. Untuk transfigurasi skala 5 menggunakan acuan tabel dibawah ini.

Tabel 1. Konversi Data Kuantitatif ke Kualitatif Skala Lima

\begin{tabular}{lll}
\hline Nilai & Interval Skor & Kategori \\
\hline 1 & $5>4,22$ & Sangat Baik \\
2 & $4,21-3,41$ & Baik \\
3 & $3,40-2,61$ & Cukup \\
4 & $2,60-1,79$ & Kurang \\
5 & $<1,79$ & Sangat Kurang \\
\hline
\end{tabular}

\section{Hasil dan pembahasan}

Perolehan dari hasil penelitian dan pengembangan, sebagai penggunaan Wordwall untuk pembelajaran Bahasa Inggris. Pada tampilan awal Wordwall ialah terdapat pilihan pembelajaran seperti tes dan latihan tagihan. Pada tampilan tes dan latihan tagihan peserta didik secara langsung belajar kemahiran dalam ketepatan mereka seperti mencocokan kosakata yang tepat berdasarkan dari slide yang mereka lihat. Berikut gambar yang ada pada media Wordwall.net yang bisa dipilih oleh pendidik pada saat pembelajaran perbendaharaan kosakata dengan media Wordwall.

Pada tahap awal peserta didik mengalami kesulitan dalam mengakses wordwall.net. Pendidik memberikan contoh bagaimana menggunakan gawai 
tersebut. Setelah peserta didik memahami bagaimana mengaplikasikannya didalam pembelajaran menyatakan terdapat perbedaan. Pembelajaran kosakata yang biasanya membosankan, lebih menyenangkan dengan lansung mengetahui hasil yang bdiperoleh.

Sedangkan hasil analisis Annisa Nur, 2017 mengangkat tentang wordwall mengatakan bahwa pendidik masih memilih menggunakan bahan ajar yang monoton tidak bervariasi, khususnya dalam pembelajaran kosakata. Sehingga dalam kegiatan pembelajaran kosakata ditambahkan variabel materi teks dekriptif dengan menggunakan wordwall.

Analisis oleh Dwi Yunas, 2015 dalam menggunakan wordwall mengintegrasikan beberapa jenis tampilan yang ada dalam wordwall dalam penyampaian pembelajaran tersebut. Dari pembahasan dua penelitian tersebut, dapat disimpulkan bahwa penggunaan wordwall dapat diimplementasikan dalam pembelajaran kosakata.

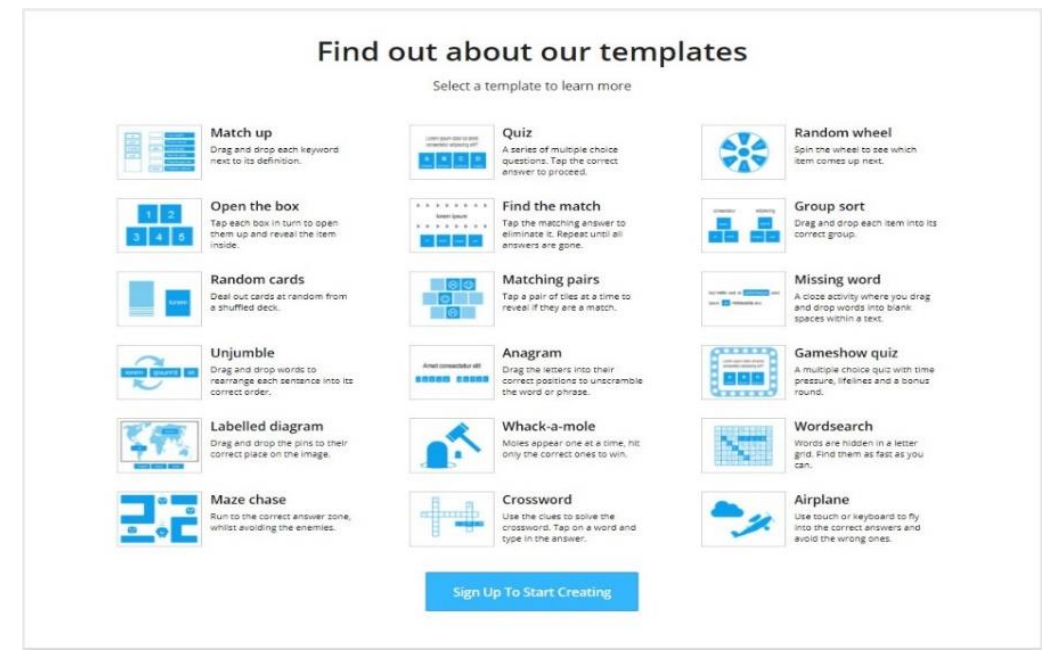

Gambar 2. Tampilan Wordwall (sumber:https:////wordwall.net)

Hasil produk yang selesai dikembangkan, untuk itu diperlukan konfirmasi dari para pakar materi dan pakar media. Proses verifikasi bahan ajar bertujuan untuk menghitung tingkat valid dan layak bahan ajar yang digunakan dalam wordwall. Penyajian materi wordwall ialah guru memilih dari salah satu template yang telah diberikan dari perbendaharaan kosakata yang dikerjakan oleh peserta didik. Terdapat beberapa hal yang perlu di konfirmasi oleh pakar materi. Meliputi empat komponen yaitu, mengetahui kesesuaian bahan ajar, tercapainya komponen penyampaian materi, serta ketepatan tes dan latihan. 


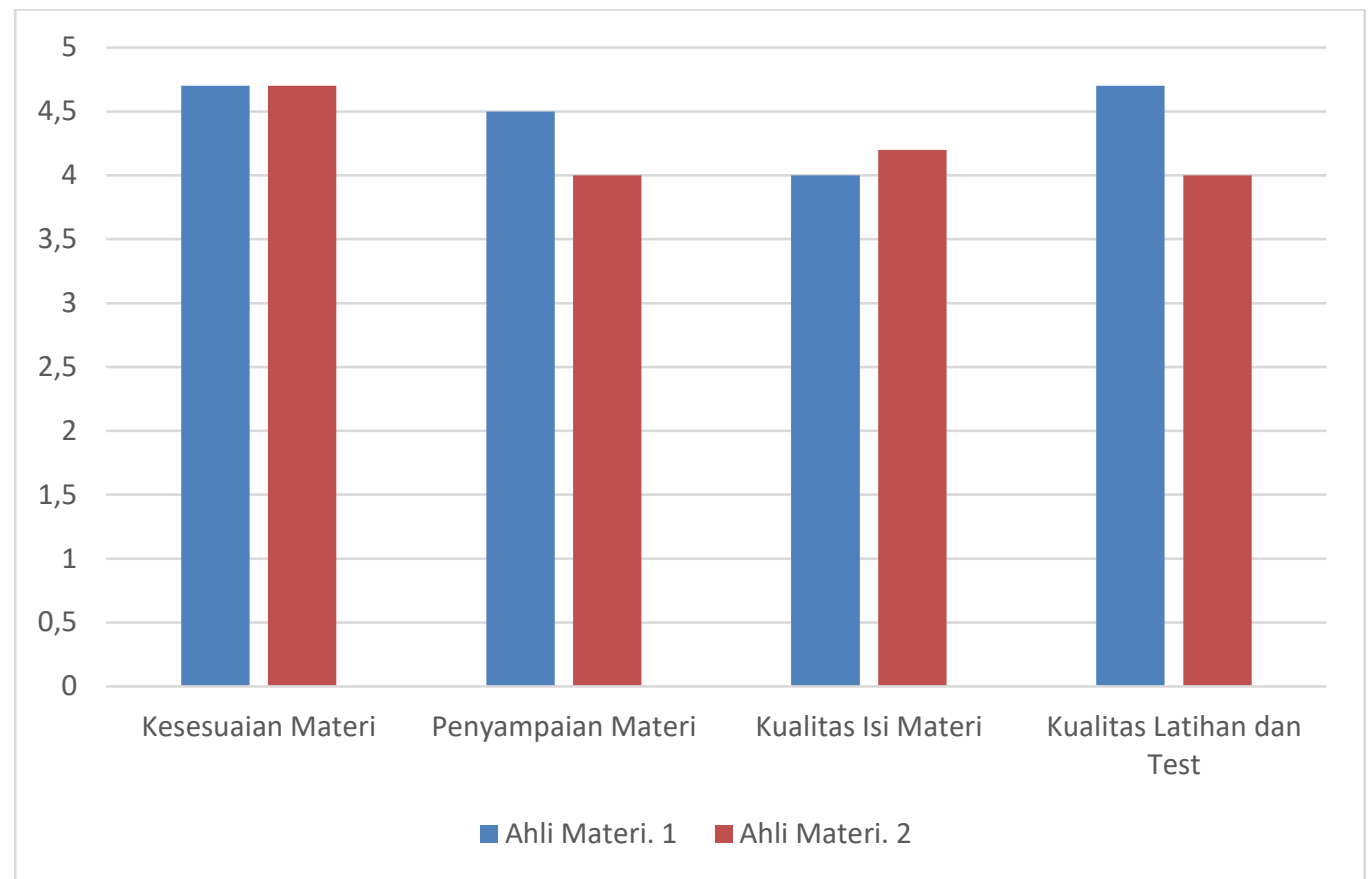

Gambar 3. Hasil validasi dari pakar bahan ajar.

Berdasarkan pemaparan tabel analisis data dan persentase untuk hasil penilaian dari ahli materi diketahui mendapatkan tingkat 4 "sangat baik" dengan mendapatkan rata-rata nilai 4,34 .

Tahap berikutnya adalah pakar media yang bertujuan melihat langkah kesesuaian bahan ajar, hal ini diperhitungkan menuju ke langkah pra pengembangan selanjutny. Pakar media, mendapatkan penilaian media yang bertujuan untuk mengetahui lelebihan dari penggunaan gawai tersebut. Untuk penggunaan validasi gawai diturunkan menjadi lima aspek. Sudut pandang yang pertama kegiatan proses penyampaian materi, kedua bentuk instrumen antar muka, ketiga pedagogy, keempat meliputi informasi tambahan dan kelima adalah aspek yang terakhir adalah fitur tak tampak. 


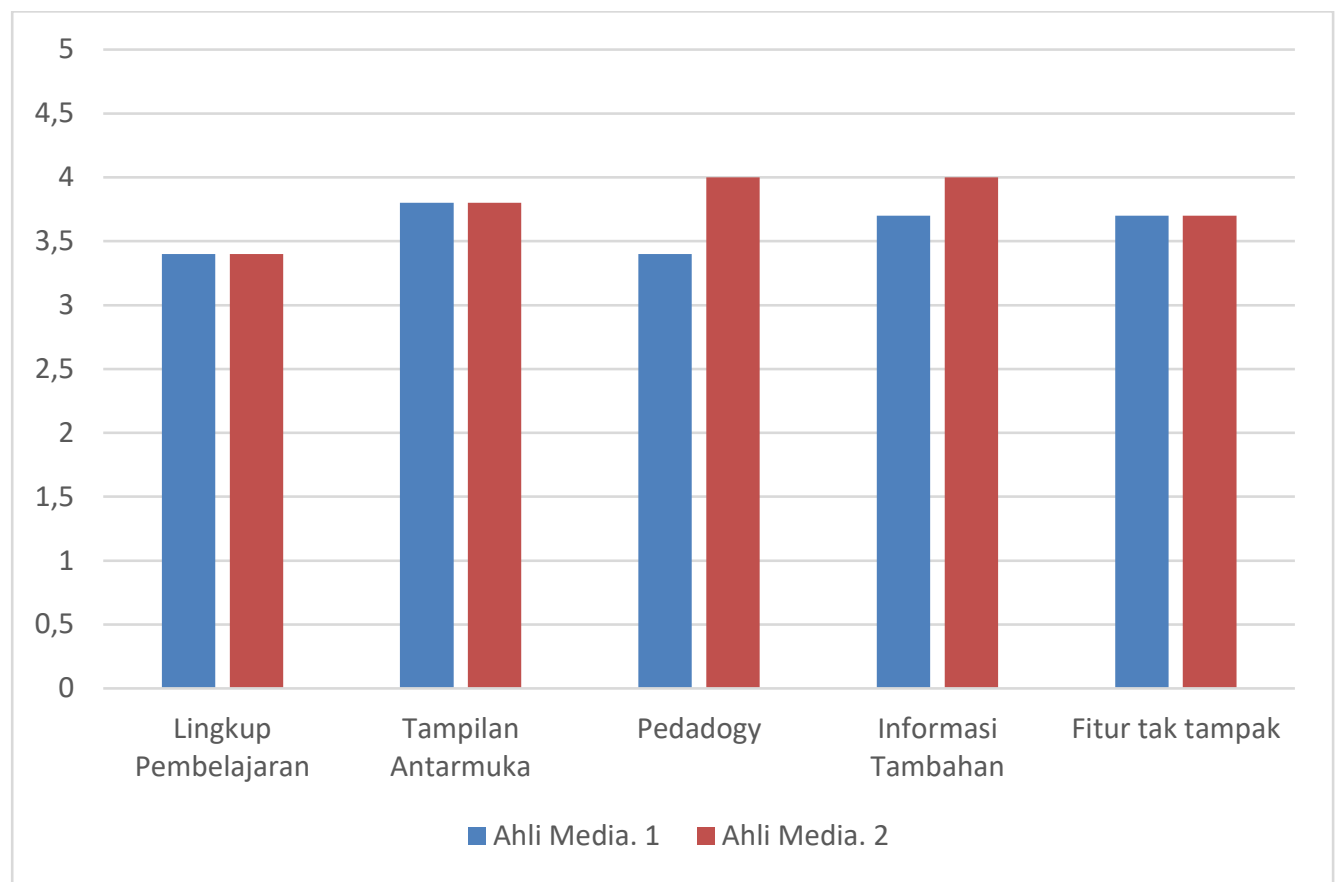

Gambar 4. Hasil validasi pakar instrumen

Hasil analisis data dan presentase menurut penilaian ahli materi diketahui, bahwa kualitas wordwall untuk pembelajaran bahasa Inggris khususnya perbendaharaan kosakata siswa kelas VII untuk UPT SMPN 34 Bandar Lampung masuk kategori "baik" dengan rerata skor menunjukkan 3,70. Untuk 6 peserta didik dilakukan uji beta, 2 peserta didik untuk menggantikan level atas, 2 peserta didik menggantikan untuk level sedang kemudian 2 peserta didik menggantikan level bawah,.

Untuk mengetahui sejauh mana yang di uji beta hal ini dinilai berkaitan dengan kualitas wordwall dan kelayakan materi. Komponen dari 15 aspek tersebut meliputi, kejelasan dalam bentuk petunjuk penggunaan wordwall, kejelasan untuk mencapai proses penerimaan materi dengan baik, pemahaman bahan ajar yang diberikan, keterbacaan wacana atau tulisan dengan jelas, kejernihan suara, penulisan contoh saling terhubung, pemberian materi tugas, pembagian evaluasi, tersusunnya langkah tes sampai proses menyelesaikan, evaluasi yang saling berkaitan, respon peserta didik, kejelasan bahasa, aktualisasi gambar, keleluasaan memilih daftar, mengembangkan motivasi pembelajaran bagi peserta didik. Kemudian dari akhir kajian rata-rata 4,30 termasuk kriteria "sangat baik". 


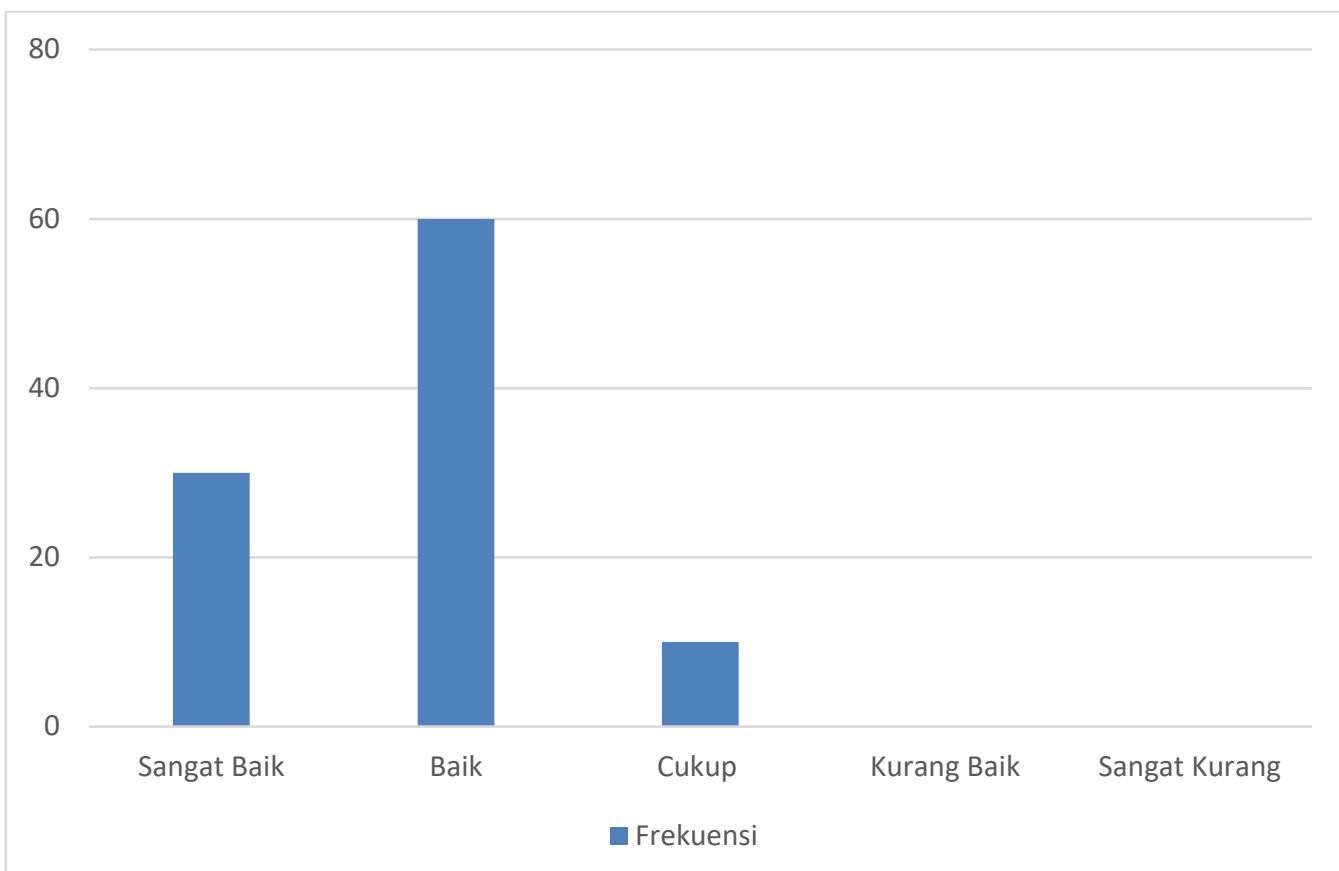

Gambar 5. Hasil beta dari uji beta

Tes sumatif diberikan kepada 31 peserta didik yang di khususkan bagi peserta didik kelas VII. Pelaksanaan penilaian analisis melalui tahap pra ujian dan sesudah ujian. Informasi perolehan pra ujian dan sesudah ujian yang didapat sehingga disamakan guna memahami sejauh mana peningkatan proses pembelajaran antara pra ujian dan sesudah ujian menggunakan pemanfaatan wordwall saat pembelajaran Bahasa Inggris. Berikut disajikan tabel komparasi pra ujian dan sesudah ujian.

\begin{tabular}{lcc}
\multicolumn{2}{c}{ Tabel 2. Perbandingan Hasil Pretest dan } & Posttest \\
\hline \multicolumn{1}{c}{ Variabel } & Pretest & Posttest \\
\hline Nilai Terendah & 72,5 & 92,5 \\
Nilai Tertinggi & 90 & 100 \\
Rata-rata & 78,94 & 96,13 \\
Gain & 17,19 &
\end{tabular}

Hasil perolehan dari komparasi kepada peserta didik yakni sebelum dan sesudah mendapatkan perlakuan wordwall terjadi perubahan peningkatan pembelajaran sebesar 17,19\% pada peserta didik kelas VII UPT SMPN 34 Bandar Lampung dalam pembelajaran perbendaharaan kosakata melalui pemanfaatan wordwall. 


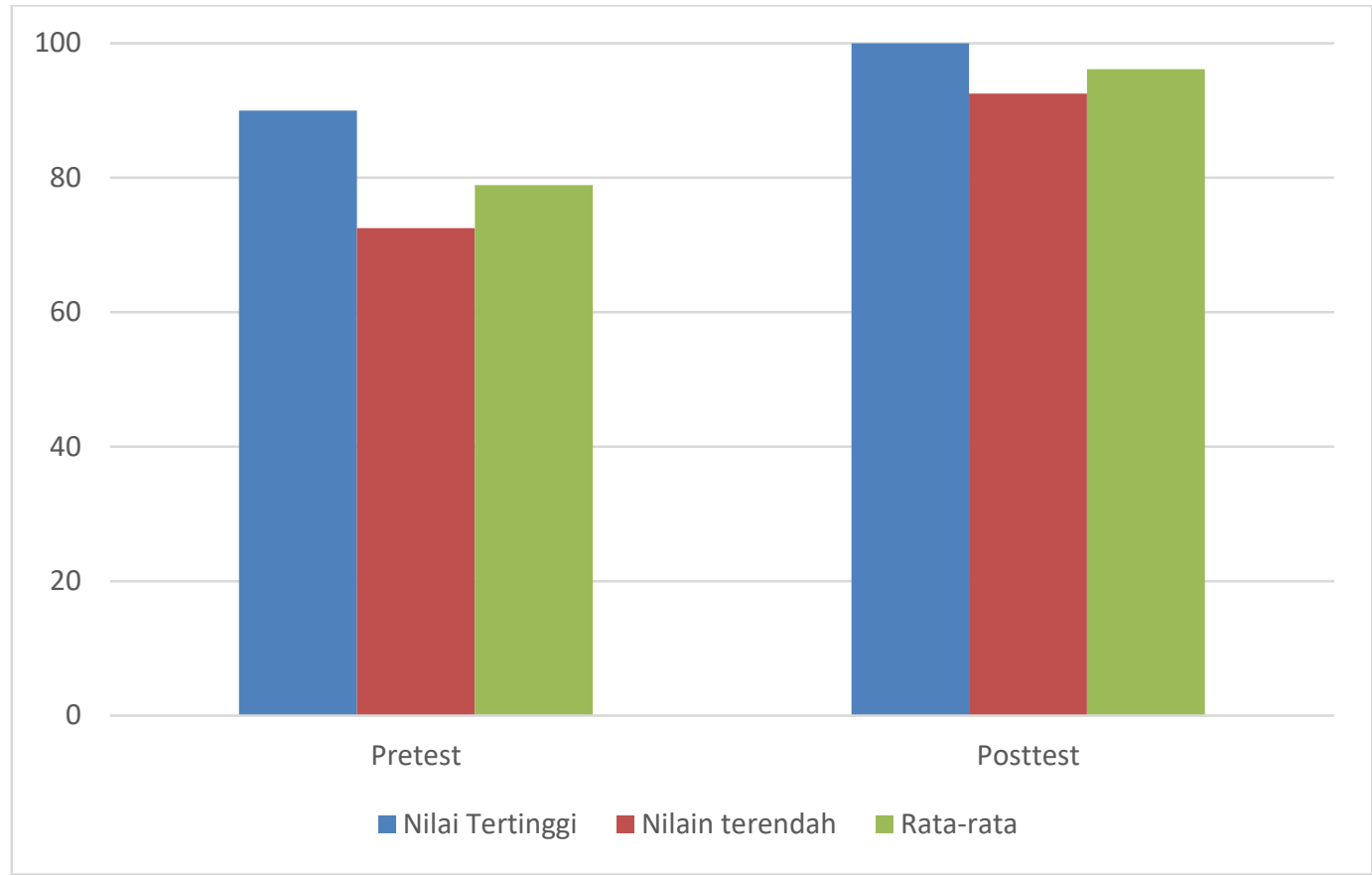

Gambar 6. Hasil evaluasi sumatif

\section{Simpulan}

Berdasarkan hasil analisis data dan pembahasan yang diperoleh dalam pemanfaatan media wordwall untuk pembelajaran dapat disimpulkan bahwa produk wordwall dalam pembelajaran Bahasa Inggris untuk menambah perbendaharaan kosakata bagi peserta didik SMP kelas VII dinilai efektif. Penggunaan wordwall dapat diterapkan lansung melalui facebook, goggle classroom, twitter, atau dikirim link melalui grup WA. Pembelajaran menggunakan wordwall ini dapat dilakukan dengan cara tatap muka, tidak tatap muka (offline) dan jarak jauh (online).

Kelayakan media wordwall untuk kemampuan perbendaharaan kosakata bagi peserta didik SMP kelas VII. Terdapat pembeda hasil yang diberikan oleh para pakar materi pada saat melakukan uji alpha. Pakar materi pertama memberikan penilaian 4,60 termasuk " sangat baik"sedangkan yang kedua memberikan nilai 4,08 melalui validasi oleh ahli materi pertama diperoleh penilaian sebesar 4,60 termasuk "baik".

Untuk perolehan yang didapat yang diberikan oleh pakar media pertama diberikan nilai 3,60 termasuk "baik" dan nilai 3,80 termasuk "baik" oleh pakar media yang kedua. Kemudian hasil penilaian latihan bagi pengguna media wordwall sebesar 4,30 termasuk "sangat baik" dalam meningkatkan kemampuan perbendaharaan kosakata khususnya dalam pembelajaran bahasa Inggris SMP kelas VII. Dari data menunjukan, proses pembelajaran yang dilakukan oleh peserta didik mencapai peningkatan. Nilai yang didapat peserta didik sebelum dan sesudah dikenalkan tentang pemanfaatan media wordwall dalam menambah perbendaharaan kosakata memiliki ketuntasan peserta didik mencapai $100 \%$. 
Akhir dari analisis membuktikan pemanfaatan media wordwall efektif untuk menambah perbendaharaan kosakata peserta didik. Untuk implementasikan dapat secara synchronous, asynchronous atau campuran keduanya pada saat pembelajaran. Alasan implementasi tersebut dilaksanakan dengan campuran yakni penggabungan online dan konvensional untuk mengetahui sejauh mana hasil yang dicapai oleh peserta didik. Terdapat $17,19 \%$ diperoleh dalam peningkatan hasil belajar pada penelitian ini.

Kesimpulan dari hasil penelitian ini memberikan manfaat pada penyegaran proses pendidikan dalam hal ini khususnya di dalam lingkungan SMP Negeri 34 Bandar Lampung dan terutama dalam proses kegiatan pembelajaran Bahasa Inggris di sekolah Bersama peserta didik. Bagi pendidik memberikan warna dalam pembelajaran perbendaharaan kosakata dari yang konvensional menjadi aplikatif. Sedangkan siswa merasa penasaran dengan menggunakan media wordwall, kelas menjadi hidup dan pembelajaran tidak jenuh.

Pemanfaatan produk dari media wordwall ini dapat dipakai sebagai bahan ajar basis alternatif bagi peserta didik pada pembelajaran Bahasa Inggris sehingga memperkaya perbendaharaan kosakata sehingga dapat disebarluaskan di sekolah-sekolah SMP/MTs.

\section{Daftar rujukan}

Allesi,, S. M., \& Trollip,, S. P. (2001). Multimedia for Learning: methods and development(3rd ed). Boston: Allyn and Bacon.

Arrosyida, A., \& Suprapto. (2015). Media Pembelajran Interaktif Jaringan Komputer Menggunakan Macromedia Flash Di SMK Negeri Saptosari. Jurnal pendidikan Informatika.

Carey, J. O., \& Dick, W. C. (2006). The Systematic Design of Instruction. New York: Pearson.

Elfrieda, H. H., \& Michael , L. K. (2003). Teaching and Learning Vocabulary Research to Practice. Cambridge Language Teaching Library UK, h 83.

Fitriani, A. N. (2017). Google Scholar. Retrieved from Google Scholar: http://mulok.library.um.ac.id/index3.php/86953.html

Gagne, R. M. (2005). Principles of Instructional Design. New York: Wadsworth Publishing Co.

Herlina. (2015). Meningkatkan Pemahaman Kosakata Bahasa Inggris Melalui Metode Permainan Bingo. Jurnal Ilmiah VISI PPTK PAUDNI, VOL. 10, No.2.

Putranto, D. Y. (2015). Google Scholar. Retrieved from Google Scholar: http://mulok.library.um.ac.id/index3.php/78707.html

Schmitt, N., \& Schmitt, D. (2014). A Reassessment of Frequency and Vocabulary Size in L2 Vocabulary Teaching. Language Teaching, pp. 484-503.

Wagstaff, J. M. (1999). Teaching Reading and Writing With Word Wall. U.S.A: Scholastic Inc.

Xiqin, L. (2008). A Study of Teaching Strategies to Improve Junior English Vocabulary. University Guangzhou, 2.

Richards, J. C., Gallo, P. B., \& Renandya, W. A. (2001). Exploring teachers' beliefs and the processes of change. PAC Journal, 1(1), 41-58. 
Pemanfaatan media wordwall dalam peningkatan perbendaharaan kosakata (vocabulary) pada pembelajaran bahasa Inggris

Wang, J., Elicker, J., McMullen, M., \& Mao, S. (n.d.). Chinese and American preschool teachers" beliefs about early.

White, M. J., \& Bruning, R. (2005). Implicit writing beliefs and their relation to writing quality. Contemporary Educational Psychology, 3o(2), 166-189. 